\title{
KOMIK EDUKASI JAJANAN SEHAT
}

\author{
Gagat Ekasakti Pertiwi ${ }^{1}$, I Dewa Alit Dwija P. ${ }^{2}$, Didit Widiatmoko Soewardikoen ${ }^{3}$ \\ 1,2,3 Universitas Telkom
}

\begin{abstract}
Abstrak: Perkembangan anak yang sedang tumbuh akan optimal jika didukung oleh makanan dengan gizi seimbang. Umumnya pertumbuhan dan perkembangan berlangsung pada usia sekolah dasar, di mana sebagian besar makanan mereka berasal dari konsumsi makanan ringan di lingkungan sekolah. Tapi ternyata tidak semua makanan ringan di lingkungan sekolah sehat dan layak untuk dikonsumsi. Hal ini dapat disebabkan oleh faktor lingkungan dan manusia. Berangkat dari masalah, penulis merasa perlu untuk media pembelajaran yang berisi informasi tentang jajanan sekolah yang sehat. Data diperoleh melalui metode observasi, studi literatur, wawancara. Menggunakan analisis matriks, diperoleh konsep bahwa informasi buku dikemas dengan gambar yang menarik bisa menjadi salah satu media pembelajaran yang cukup efektif untuk anak-anak. Maka media yang paling tepat untuk usia sekolah dasar adalah buku komik pendidikan yang dikemas dalam bentuk komik serial untuk membuat belajar lebih menyenangkan dan tidak membosankan. Setelah membaca buku ini, anak-anak di sekolah lebih peduli dan cerdas dalam memilih makanan untuk konsumsi mereka sehingga bisa tumbuh sehat, tidak mudah sakit dan memenuhi gizi.
\end{abstract}

Kata kunci: komik, pendidikan anak, makanan sehat

\begin{abstract}
The child development will continue optimally if it is supported by balanced nutrition. In general, the child growth and development takes place at primary school age, in which most of foods they consume coming from varied snacks in their school environment. Unfortunately, most of those foods are unhealthy and bad for human consumption due to the environmental and individual factors. Referring to this phenomenon, the researcher is determined to create a learning media informing about healthy school snacks. Data was obtained from observation, the study of literature, and interview. By using matrix analysis, it is concluded that the book created with interesting pictures can be one of effective learning media for children. The most appropriate learning media for primary students is the serial comic books to create fun learning atmosphere. It is
\end{abstract}

Penulis adalah mahasiswa dan staff pengaja jurusan Desain Komunikasi Visual, Fakultas Industri Kreatif Universitas Telkom, email: dwijaputra772@gmail.com 
expected that after reading the educative comic book, these students will be smarter and aware of choosing foods for their consumption, therefore they can live in healthy and vigorous condition.

Keywords: comic, children education, healthy food

\section{PENDAHULUAN}

Bagi anak-anak, sangat penting untuk mereka menjalani pola makan yang sehat guna mendapatkan gizi yang seimbang bagi tubuhnya. Melalui pola makan yang sehat, gizi seimbang terpenuhi dan akan berpengaruh positif terhadap kesehatan serta tumbuh kembang anak (M, Winda A., 2013). Gizi seimbang bisa didapat jika tingkat kecukupan energi dan protein terpenuhi. Namun di Indonesia, konsumsi energi dan protein pada anak masih berada di bawah angka kecukupan, yaitu hanya setengah dari jumlah yang dianjurkan Dinas Kesehatan.

Menurut psikolog Wiwik Idaryati, usia anak-anak atau sekitar 6 sampai 12 tahun sedang berada pada tahap pertumbuhan dan perkembangan. Dengan waktu hampir 35 jam per minggunya di sekolah dibutuhkan asupan untuk memenuhi kebutuhan gizi mereka, salah satunya jajanan sekolah. Berdasarkan Laporan Akhir Monitoring dan Verifikasi Profil Keamanan Pangan Jajanan Anak Sekolah (PJAS) Nasional tahun 2008 menunjukkan bahwa hampir semua anak memilih jajan di sekolah, hanya $1 \%$ anak yang tidak jajan. Kebiasaan seperti ini ada baiknya diimbangi dengan kualitas jajanan yang baik dan pengetahuan dasar tentang jajanan sehat.

Salah satu alternatif media yang dapat digunakan untuk mengedukasi anak-anak adalah buku. Kegiatan membaca buku sendiri mempunyai beberapa kelebihan, diantaranya melatih konsentrasi, melatih kemampuan berpikir logis, mengembangkan imajinasi serta kreatifitas, dan masih banyak lagi. Dengan 
membaca, pesan dalam buku lebih mudah diingat oleh anak dan bertahan lebih lama (www.bimba-aiueo.com, 2013). Buku yang menginformasikan tentang jajanan sehat dan bagaimana kualitas jajanan sehat di sekolah masih sangat jarang dijumpai apalagi dalam bentuk komik dengan karakter tokoh yang lucu. Media internet sendiri belum efektif untuk anak Sekolah Dasar. Anak seusia tersebut lebih cenderung memilih game dibanding mencari informasi kesehatan.

Berdasarkan permasalahan di atas, penulis menganggap perlunya sebuah buku informasi berupa komik edukasi sebagai media pembelajaran untuk anak mengenali jajanan sehat. Nantinya buku ini dapat meningkatkan pengetahuan anak seputar jajanan sekolah dan ke depannya diharapkan anak memiliki inisiatif dalam memutuskan jajanan seperti apa yang layak untuk dikonsumsi.

\section{KAJIAN TEORI}

Beberapa ahli buku anak mempunyai pendapat masing-masing untuk menentukan ragam jenis bacaan anak. Menurut Murti Bunanta (2008:29), ragam bacaan anak terbagi dua yaitu fiksi dan non-fiksi. Menurut Melrose, terdapat tiga elemen yang perlu diperhatikan ketika membuat buku cerita anak, yaitu storyline, karakter dan sudut pandang (Melrose, 2004:15-41).

Guna merancang sebuah buku yang baik, seorang desainer harus memahami tentang teori tata letak yang biasa dikenal dengan layout; merupakan prinsip-prinsip dalam desain seperti keseimbangan, penekanan, irama, dan kesatuan. Pemahaman akan prinsip ini sangat menentukan hasil akhir dari semua pekerjaan desain yang dilakukan. Prinsip tersebut mempengaruhi setiap keputusan yang dibuat ketika membuat layout (Siebert dan Ballard, 1992:38). Di samping itu terdapat pula grid system, yaitu sebuah sistematika penataan dan penempatan elemen-elemen visual dalam sebuah bidang rancang untuk menjaga konsistensi rancangan. Grid system sangat diperlukan sebagai dasar pola dalam 
menyusun huruf dan gambar dalam jumlah banyak, seperti buku, brosur, katalog, surat kabar, dan majalah (Sihombing, 2001:90).

Dalam merancang buku anak, unsur gambar merupakan sesuatu yang sangat penting. Anak lebih suka melihat gambar dari pada tulisan. Gambar adalah bentuk simbolik atau ruang emosional yang menggantikan pengalaman fisik atau ingatan di dalam pikiran seseorang di saat dia melihatnya. Gambar dapat menampilkan informasi yang sangat kompleks (terutama konseptual, abstrak, atau informasi yang berorientasi pada proses) dengan sangat jelas (Samara, 2007:166).

\section{METODE PENELITIAN}

Penulis melakukan observasi seputar permasalahan PJAS di Indonesia, memperhatikan perilaku anak-anak di sekolah-sekolah dasar yang jajan di kantinkantin yang tersedia di sekolahnya. Mereka tidak hanya jajan di kantin-kantin yang tersedia tapi juga di pedagang dengan gerobak atau roda. Sementara studi pustaka bertujuan untuk memperkuat perspektif dengan membaca teori-teori yang bersumber dari pemikiran ahli (Soewardikoen, 2013: 6). Untuk itu, penulis menggunakan beberapa buku, artikel resmi dan sumber lainnya yang berkaitan dengan topik sebagai sumber data yang valid. Metode wawancara dilakukan kepada beberapa narasumber, diantaranya ahli buku anak, psikolog anak dan pihak yang bertanggung jawab atas PJAS di Indonesia.

Analisis matriks digunakan untuk membandingkan buku-buku sejenis yang pernah dibuat. Analisis ini dilakukan guna menentukan kelebihan dan kekurangan buku yang pernah dibuat, sehingga buku yang dirancang memiliki perbedaan dan keunggulan dari buku yang pernah dibuat. 


\section{HASIL DAN DISKUSI}

Khalayak sasaran yang menjadi target pasar buku ini dari segi geografis merupakan penduduk Indonesia yang bertempat tinggal di kota-kota besar. Untuk target primer perancangan buku adalah anak dengan usia 9-12 tahun yang masih duduk di bangku Sekolah Dasar, kelas 4 sampai 6 SD. Anak yang ditargetkan harus memiliki rasa ingin tahu yang besar serta terbuka dengan hal-hal baru. Ditambah dengan gaya hidup membaca buku, memiliki kebiasaan jajan di sekolah, dan tinggal di lingkungan sosial yang baik.

Sedangkan target sekunder yaitu orang tua dengan rentang usia 25-40 tahun yang berpendidikan minimal sederajat SMA. Kelas sosial yang dipilih adalah menengah dan menengah karena pada kelas ini orang tua cenderung berpikiran terbuka dalam menjalankan pola hidup/makan sehat serta peduli terhadap kesehatan, terutama perkembangan dan asupan makan anak.

Dari hasil wawancara yang sudah dilakukan, penulis mengambil kesimpulan bahwa untuk saat ini pihak masyarakat lah yang dituntut untuk cerdas sebagai konsumen agar bisa terhindar dari makanan minuman berbahaya. Terutama anak-anak pada usia 4-6 SD yang aspek perkembangannya sudah cukup matang, sehingga lebih mudah dalam memberikan pemahaman mengenai suatu hal. 
Tabel 1 Matriks pembanding produk sejenis

\begin{tabular}{|c|c|c|c|c|}
\hline $\begin{array}{l}\text { Gambar } \\
\text { dan } \\
\text { Judul } \\
\text { Buku }\end{array}$ & $\begin{array}{c}\text { Aku Suka } \\
\text { Makanan Sehat }\end{array}$ & $\begin{array}{l}\text { Anak Muslim } \\
\text { Cerdas tentang } \\
\text { Halal dan Haram }\end{array}$ & $\begin{array}{l}\text { Pof } \\
\text { Why? } \\
\text { WHY? Makanan } \\
\text { dan Gizi }\end{array}$ & $\begin{array}{l}\text { Ask Kermit : Does } \\
\text { Cheese Grow on } \\
\text { Trees? A Book } \\
\text { About Food }\end{array}$ \\
\hline $\begin{array}{l}\text { Jenis } \\
\text { Buku }\end{array}$ & $\begin{array}{l}\text { Buku cerita } \\
\text { bergambar, buku } \\
\text { berseri, } \\
\text { dilengkapi lembar } \\
\text { aktifitas di akhir } \\
\text { cerita }\end{array}$ & $\begin{array}{l}\text { Buku informasi, } \\
\text { dilengkapi lembar } \\
\text { aktifitas di akhir } \\
\text { setiap bab }\end{array}$ & $\begin{array}{l}\text { Komik, buku } \\
\text { berseri }\end{array}$ & $\begin{array}{l}\text { Buku bacaan } \\
\text { bergambar, buku } \\
\text { berseri }\end{array}$ \\
\hline $\begin{array}{l}\text { Khalayak } \\
\text { Sasaran }\end{array}$ & $\begin{array}{l}\text { SD Awal (kelas 1- } \\
\text { 3), 6-9 tahun }\end{array}$ & $\begin{array}{l}\text { SD Akhir (kelas 4- } \\
6), 9-12 \text { tahun }\end{array}$ & $\begin{array}{l}\text { SD Akhir (kelas } \\
\text { 4-6), 9-12 tahun }\end{array}$ & $\begin{array}{l}\text { SD Awal (kelas 1-3), } \\
\text { 6-9 tahun }\end{array}$ \\
\hline $\begin{array}{l}\text { Karakter } \\
\text { Utama }\end{array}$ & $\begin{array}{l}\text { Seorang anak } \\
\text { perempuan } \\
\text { bernama Putri } \\
\text { Kecil dan } 3 \\
\text { binatang } \\
\text { peliharaannya, Jiji } \\
\text { si anjing, Mimi si } \\
\text { kucing dan Katu si } \\
\text { kakaktua }\end{array}$ & $\begin{array}{l}\text { Seorang anak laki- } \\
\text { laki bernama } \\
\text { Salman }\end{array}$ & $\begin{array}{l}\text { Anak laki-laki } \\
\text { bernama Komji, } \\
\text { anak perempuan } \\
\text { bernama Omji, } \\
\text { anak pewaris } \\
\text { kerajaan } \\
\text { bernama Bi-Bi } \\
\text { dan seorang } \\
\text { penyihir } \\
\text { sekaligus koki } \\
\text { bernama Nutrin. }\end{array}$ & $\begin{array}{l}\text { Dua ekor kodok } \\
\text { bernama Kermit } \\
\text { sebagai ayah dan } \\
\text { anaknya Robin }\end{array}$ \\
\hline Gambar & $\begin{array}{l}\text { Ilustrasi sebagai } \\
\text { menu utama. } \\
\text { Gaya ilustrasi } \\
\text { kartun, outline } \\
\text { jelas }\end{array}$ & $\begin{array}{l}\text { Ilustrasi sebagai } \\
\text { pelengkap - } \\
\text { dominan teks. } \\
\text { Gaya ilustrasi } \\
\text { kartun, outline } \\
\text { jelas }\end{array}$ & $\begin{array}{l}\text { Ilustrasi sebagai } \\
\text { menu utama } \\
\text { ditambah } \\
\text { beberapa foto } \\
\text { Gaya ilustrasi } \\
\text { kartun dan } \\
\text { realis, outline } \\
\text { jelas }\end{array}$ & $\begin{array}{l}\text { llustrasi sebagai } \\
\text { menu utama. } \\
\text { Gaya ilustrasi realis } \\
\text { (kecuali karakter), } \\
\text { outline jelas }\end{array}$ \\
\hline Warna & $\begin{array}{l}\text { Full color, tidak } \\
\text { ada warna } \\
\text { dominan. } \\
\text { Menggunakan } \\
\text { warna gradasi }\end{array}$ & $\begin{array}{l}\text { Full color, warna } \\
\text { dominan kuning } \\
\text { dan tosca. } \\
\text { Menggunakan } \\
\text { warna blok }\end{array}$ & $\begin{array}{l}\text { Full color, tidak } \\
\text { ada warna } \\
\text { dominan. } \\
\text { Menggunakan } \\
\text { warna blok }\end{array}$ & $\begin{array}{l}\text { Full color, warna } \\
\text { dominan hijau dan } \\
\text { kuning - coklat. } \\
\text { Menggunakan } \\
\text { gradasi }\end{array}$ \\
\hline Tipografi & Sans serif & Sans serif & $\begin{array}{l}\text { Serif dan sans } \\
\text { serif pada dialog } \\
\text { dalam balon } \\
\text { kata }\end{array}$ & Serif \\
\hline
\end{tabular}


Tabel 2 Matriks pembanding produk sejenis (lanjutan)

\begin{tabular}{|l|l|l|l|l|}
\hline $\begin{array}{l}\text { Ukuran } \\
\text { dan } \\
\text { Halaman }\end{array}$ & $\begin{array}{l}25 \times 24 \mathrm{~cm}, 32 \\
\text { halaman }\end{array}$ & $\begin{array}{l}24 \times 19 \mathrm{~cm}, 100 \\
\text { halaman }\end{array}$ & $\begin{array}{l}24 \times 18 \mathrm{~cm}, 160 \\
\text { halaman }\end{array}$ & $\begin{array}{l}21 \times 21 \mathrm{~cm}, 24 \\
\text { halaman }\end{array}$ \\
\hline $\begin{array}{l}\text { Jenis } \\
\begin{array}{l}\text { Cover } \\
\text { dan } \\
\text { Kertas }\end{array}\end{array}$ & $\begin{array}{l}\text { Hard cover } \\
\text { Art paper 120 gr }\end{array}$ & $\begin{array}{l}\text { Soft cove } \\
\text { HVS 70-80 gr } \\
\text { (biasa) }\end{array}$ & $\begin{array}{l}\text { Soft cover } \\
\text { HVS 90 gr (agak } \\
\text { tebal) }\end{array}$ & $\begin{array}{l}\text { Hard cover } \\
\text { HVS 100 gr > (tebal) }\end{array}$ \\
\hline Harga & $\begin{array}{l}\text { Buku dijual paket } \\
\text {-tidak dijual } \\
\text { satuan }\end{array}$ & Rp57.000 & Rp75.000 & Rp195.000 (\$15.06) \\
\hline
\end{tabular}

Sumber: dokumentasi pribadi

Berdasarkan hasil analisis matriks pembanding, penulis mengambil kesimpulan yaitu: buku komik edukasi dibuat berseri dan dilengkapi dengan lembar aktifitas yang berfungsi untuk mengulang dan memantapkan materi yang sudah dijelaskan. Gambar yang digunakan dalam perancangan adalah ilustrasi kartun dengan penggunaan outline yang jelas, serta memakai tipografi sans serif. Ukuran buku tidak lebih besar dari A4 dan menggunakan soft cover serta kertas HVS untuk harga yang lebih terjangkau. Karakter utama seorang anak dengan partner binatang.

Perancangan buku komik edukasi jajanan sehat ini bertujuan agar anak mampu membedakan dan cerdas dalam memilih mana jajanan yang layak untuk dirinya konsumsi. Didasari oleh konsep pesan yaitu 'mengubah perilaku konsumsi anak sekolah menjadi lebih peduli terhadap jajanan apa yang akan mereka konsumsi'.

Buku, karena dirasa sesuai dengan khalayak sasaran. Buku yang bersifat personal membuat anak lebih fokus sehingga tepat digunakan untuk media pembelajaran. Buku akan dibuat berseri untuk memudahkan perancangan, yaitu Seri ‘OH! Belajar dan Mengenal Jajanan Sekolah'. $\mathrm{OH}$ ! diambil dari kata yang biasa diucapkan anak-anak ketika mengetahui sesuatu. Terdiri dari empat buku yang masing-masing buku membahas mengenai masalah jajanan yang berbeda sebagai 
berikut, buku 1: Jajanan Aman dan Sehat, buku 2: Lingkungan Jajan yang Aman, buku 3: Menjaga Kebersihan Lingkungan, buku 4: Buat Bekal Sendiri Yuk!

Dalam pproyek ini perancangan akan difokuskan pada Buku 1. Buku komik ini terdiri dari 48 halaman, menggunakan kertas HVS 100 gr sebagai material isi buku. Jenis tersebut dipilih karena tidak terlalu tipis, harga yang terjangkau, serta tidak mengurangi kualitas warna dan desain ketika dicetak. Untuk bagian cover, dipilih jenis Soft Cover dengan bahan Art Carton 260 gr yang diberi laminasi doff. Ukuran buku adalah $24 \times 20 \mathrm{~cm}$, mengacu pada hasil analisis perbandingan proyek sejenis yang sudah dilakukan penulis dan berdasarkan pertimbangan efisiensi penggunaan kertas.

\section{Konsep Kreatif}

Konsep kreatif yang digunakan penulis adalah sebagai berikut. Komik yang dilengkapi lembar aktifitas, menjadikan buku ini sebagai media pembelajaran yang mudah dipahami dan menyenangkan. Penggunaan jenis buku komik didasari atas kemampuan membaca anak usia 9-12 tahun yang sudah mengerti alur panel dengan tulisan yang mulai padat. Informasi yang sekiranya cukup rumit untuk usia SD digambarkan dengan ilustrasi dan penjelasan yang lebih singkat sehingga mudah dipahami dan lebih komunikatif. Pemilihan buku komik berseri ditujukan agar lebih menarik ketika proses promosi-penjualan, selain itu harga buku bisa lebih terjangkau.

Karakter, dipilih yang seusia dan sesuai dengan tema perancangan yaitu anak-anak usia Sekolah Dasar, ditambah dua rekannya yang merupakan binatang kucing. Rupa dan tingkah laku karakter yang lucu, nakal serta dekat dengan keseharian anak diharapkan disukai, berkesan dan mudah diingat, sehingga dapat menjadi panutan yang baik bagi mereka. 


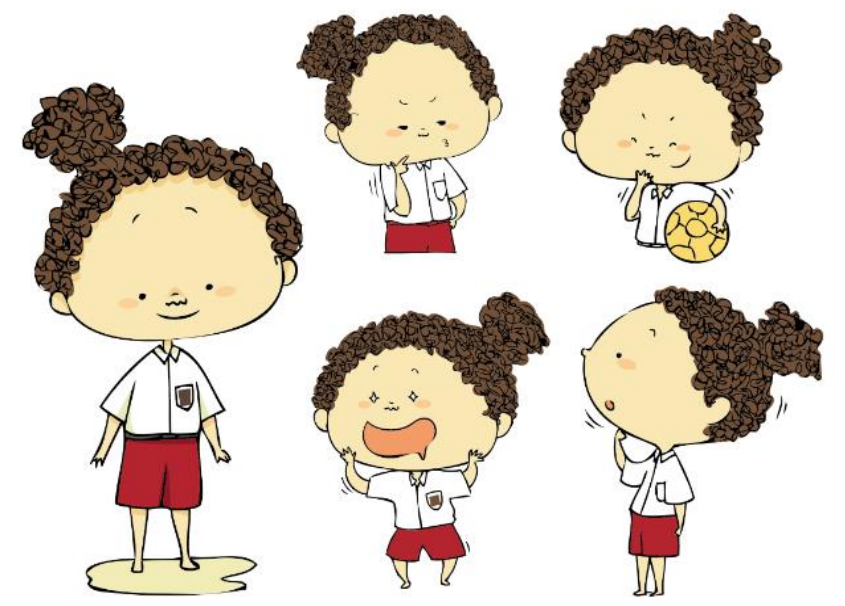

Gambar 1 : Karakter Kiting, Sumber : Dokumentasi pribadi

Ilustrasi yang digunakan dalam perancangan buku ini adalah kartun sederhana, dengan teknik tracing gambar manual. Ilustrasi menggunakan outline yang jelas agar memudahkan anak mengenali gambar. Ilustrasi dibuat agak ekspresif, sehingga anak tertarik memahami isi buku. Warna yang digunakan untuk karakter dan background adalah campuran dari warna panas dan warna dingin. Untuk gaya pewarnaan yang dipilih adalah pewarnaan blok.

Tipografi yang dominan digunakan dalam perancangan ini adalah jenis Sans Serif dipadukan dengan Script, yang menghasilkan bentuk seperti tulisan tangan. Bentuk ini memberi kesan sederhana, lugas, dan dinamis yang sesuai dengan karakter anak-anak. Aspek legibility dan readability yang tinggi juga menjadi pertimbangan utama dalam memilih font ini.

Agar cerita dapat mengalir dan memudahkan dalam pembuatan visual, penulis membuat alur ceritanya lebih dahulu (storyline). Cerita diawali dengan Kiting dan teman-teman yang sedang bermain bola saat jam istirahat sekolah. Selesai bermain bola mereka merasa lapar dan memutuskan untuk makan di kantin sekolah. Namun Kiting teringat jajanan depan sekolah yang beragam, pikir Kiting mulai nakal padahal mama sudah melarang Kiting jajan diluar sekolah. 
Diluar sekolah Kiting sangat senang dan jajan banyak sekali. Tanpa sadar dua kucing mengamatinya, mereka adalah Ciko dan Coki, kucing pelindung anakanak yang berasal dari dunia kucing. Tak berapa lama setelah makan jajanannya Kiting merasakan sakit di perutnya, Ciko Coki yang sudah menduganya langsung menghampirinya. Tiba-tiba 'BOOOM!' Ciko Coki berubah ke wujud besarnya. Kiting yang terkejut tak bisa berkata apa-apa saat Ciko Coki memperkenalkan diri mereka.

Disaat Kiting bingung, Coki memberi Kiting obat untuk meredakan sakit perutnya. Barulah setelah sembuh Kiting bertanya pada Ciko Coki. Mereka menjelaskan asal usul mereka dan maksud kedatangan mereka. Kiting pun mulai antusias, diawali dengan pertanyaan 'kalau begitu kalian tahu kenapa aku sakit perut?' dan petualangan pun dimulai.

Ciko memberikan Kiting gelang yang bisa merubah wujud mereka menjadi kecil. Mereka bertiga menaiki kapal Ciko Coki dan berangkat mundur ke pagi hari ketika Kiting berangkat sekolah. Dari sanalah penjelasan Ciko Coki bermula, dari pentingnya makan teratur, pengelompokkan jajanan, gizi seimbang, cemaran pada makanan (biologis, kimia dan benda lain), sampai label kemasan.

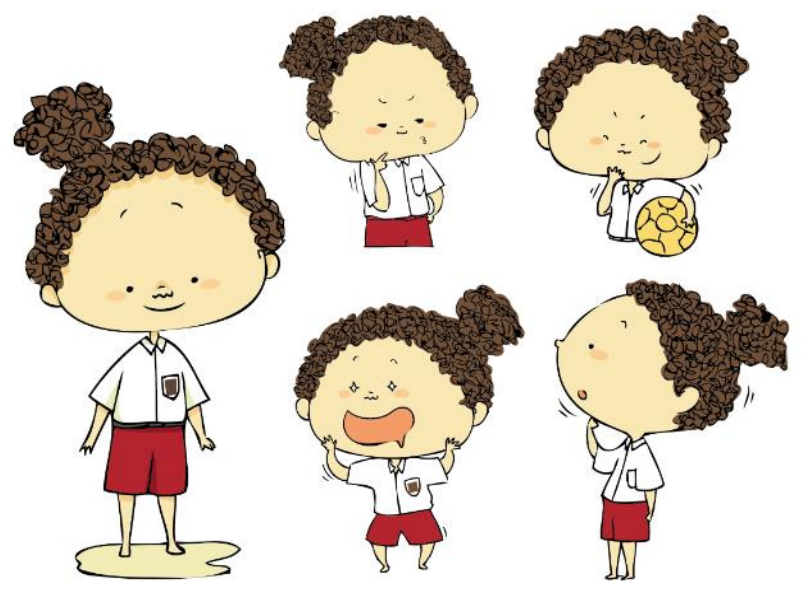

Gambar 2 Perbandingan karakter Kiting, Coki, dan Ciko Sumber: Dokumentasi pribadi 
Sudut pandang yang dipakai adalah sudut pandang objektif. Hal ini karena jenis buku yang di rancang merupakan buku komik informasi dan biasa menggunakan sudut pandang ini. Dalam buku ini terdapat tiga karakter utama yaitu seorang anak kecil bernama Kiting dan dua ekor kucing ajaib bernama Ciko dan Coki. Serta beberapa karakter pendamping.
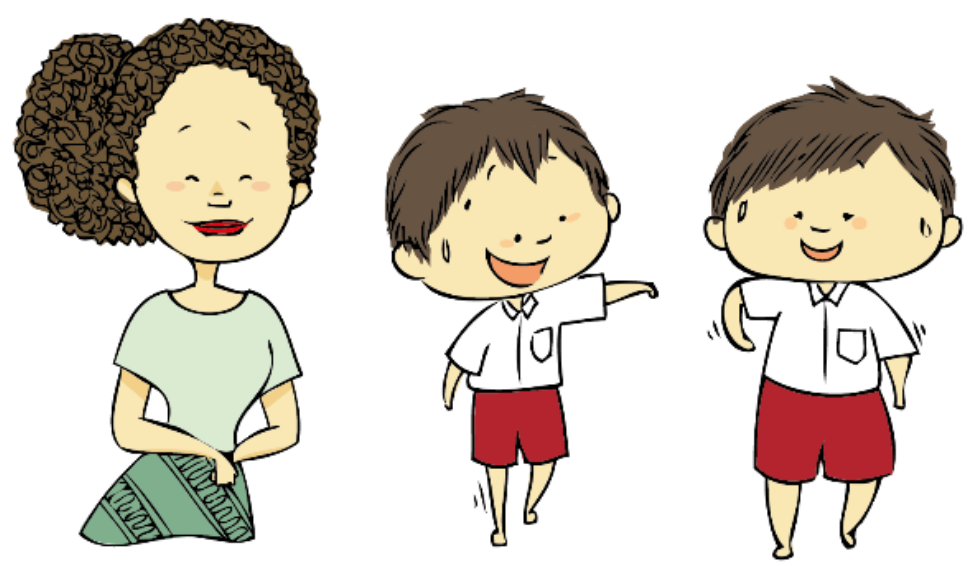

Gambar 3 Mama, Eja dan Aji

Sumber: Dokumentasi Pribadi

\section{Hasil Perancangan}

Seri ‘OH! Belajar dan Mengenal Jajanan Sekolah' terdiri dari empat buku. Keempat buku memiliki kesamaan layout, dan dibedakan dengan ilustrasi sampul yang merepresentasikan isi materi masing-masing buku. Tiap buku memiliki tema warna berbeda agar menarik dan mudah dibedakan (Gambar 4). 

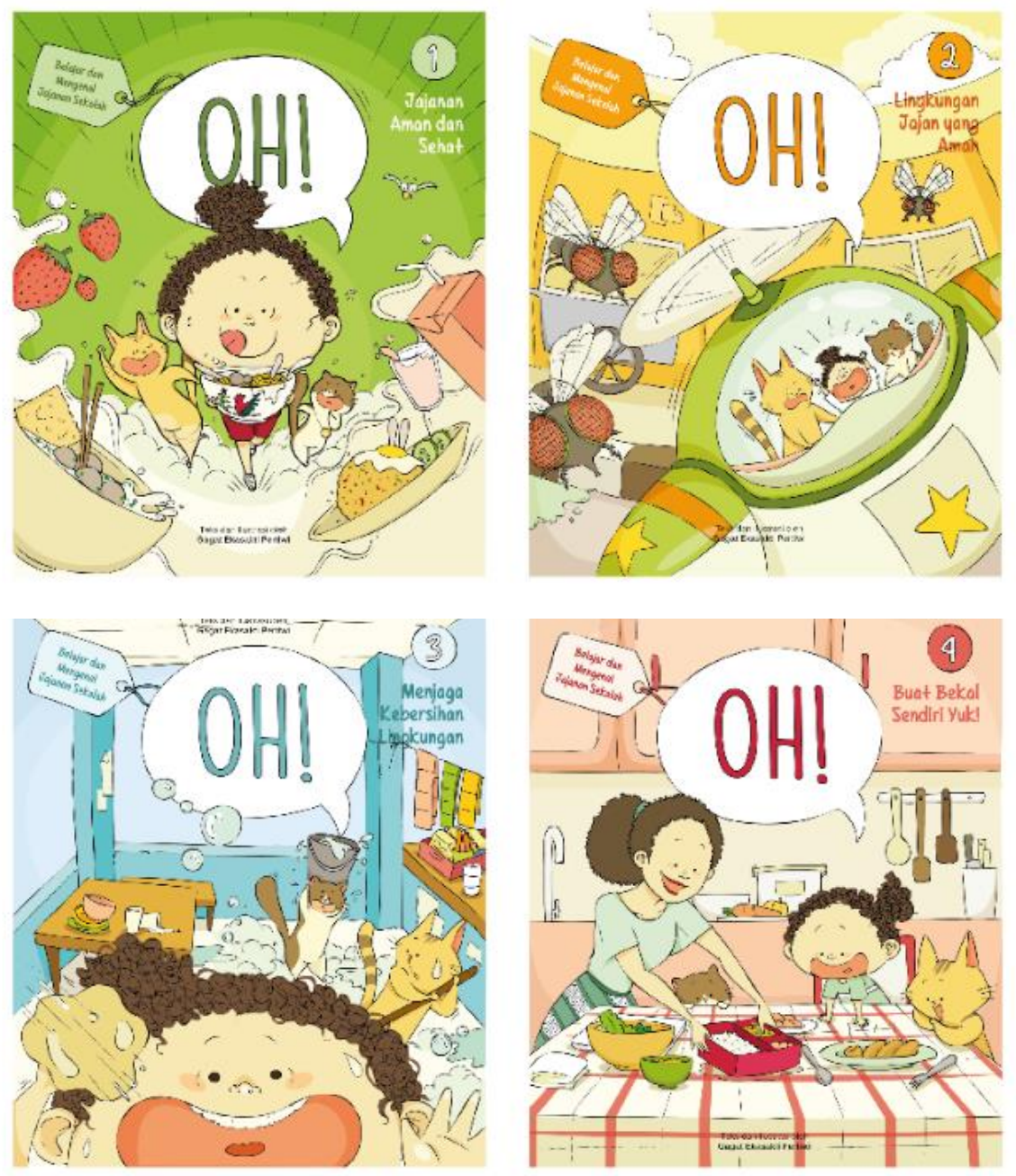

Gambar 4 Sampul depan seri 4 buku "OH" Sumber : Dokumentasi Pribadi

Desain isi atau bagian dalam buku menggunakan grid system yang bervariasi. Hal ini untuk menghindari kemonotonan dan kejenuhan dengan tata letak yang sederhana. Di samping itu, agar keterbacaan dan alur ceritanya mudah ditangkap oleh target sasaran yaitu anak Sekolah Dasar. Berikut merupakan beberapa contoh halaman hasil rancangan buku "OH! Belajar dan Mengenal Jajanan Sekolah: Jajanan Aman dan Sehat" (Gambar 5). 

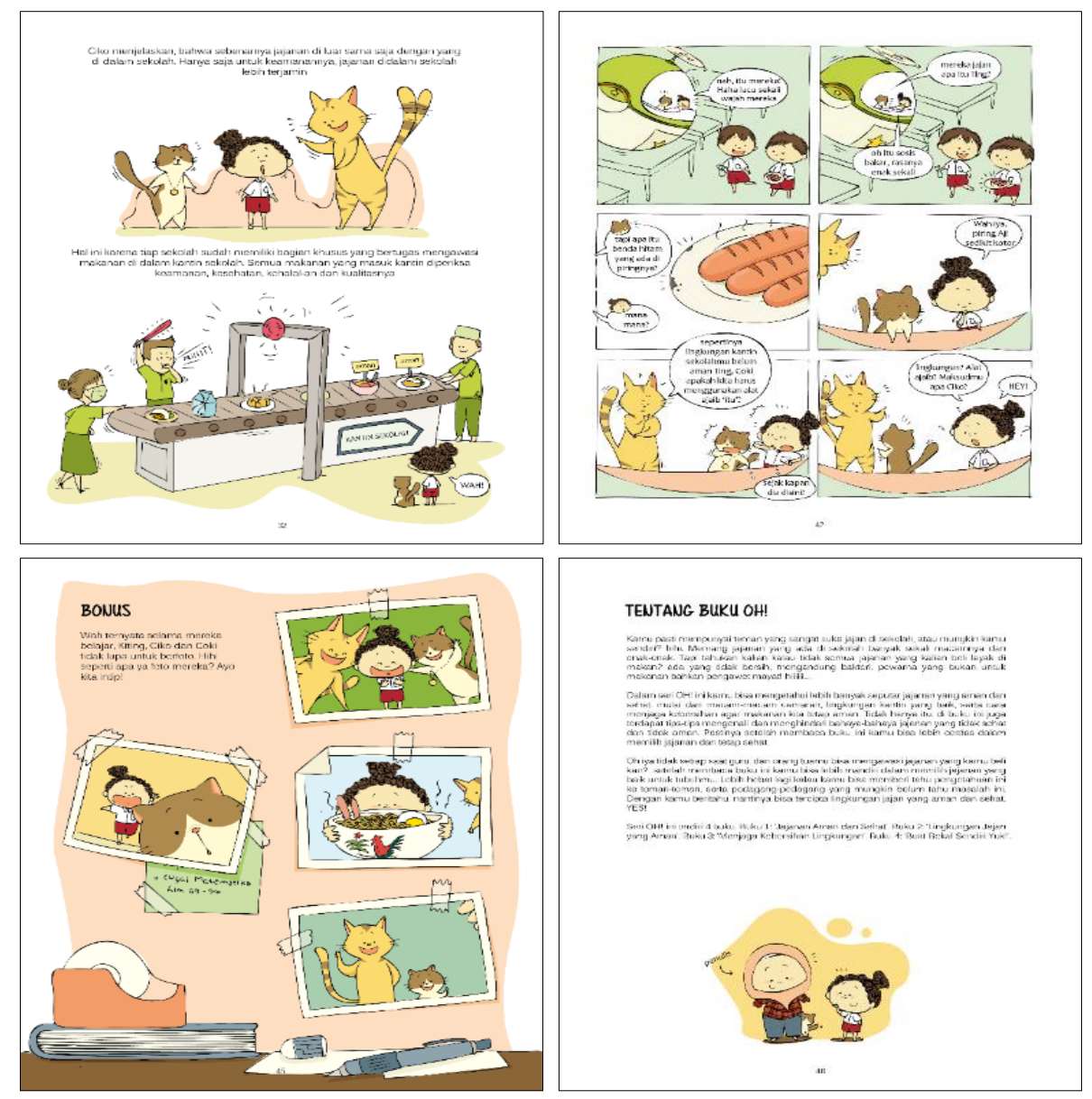

Gambar 5 Sampel isi buku

Sumber: Dokumentasi Pribadi

\section{KESIMPULAN}

Perancangan ini dilakukan karena kurangnya keberadaan media lokal, terutama buku anak yang membahas mengenai kesehatan dan keamanan jajanan sekolah. Diharapkan setelah muncul seri 'OH! Belajar dan Mengenal Jajanan Sekolah', anak-anak mendapatkan buku yang tepat dan sesuai dengan masalah yang ada di lingkungannya.

Penggunaan dan pemilihan media buku komik edukasi ini dapat menjadikan kegiatan belajar lebih menyenangkan dan tidak membosankan. Di samping itu, dengan adanya contoh kasus dan lembar aktifitas pada setiap materinya dapat membuat anak benar-benar memahami dan mengaplikasikan materi ke kesehariannya, tidak hanya 
sekedar tahu. Dengan demikian, semakin banyak anak yang memahami dan peduli akan pentingnya keamanan dan kesehatan jajanan sekolah. Orang dewasa dan pihak-pihak yang bersangkutan pun dituntut untuk dapat turut serta bersama-sama menciptakan lingkungan sekolah yang aman, sehat dan kondusif.

\section{DAFTAR PUSTAKA}

Bunanta, M., 2008. Buku, Mendongeng dan Minat Membaca. Jakarta: Kelompok Pecinta Bacaan Anak.

Melrose, A., 2004. Write for Children. London: RoutledgeFalmer.

Samara, T., 2007. Design Elements: A Graphic Style Manual: Understanding the Rules and Knowing When to Break Them. United States: Rockport Publisher.

Siebert, L. \& Ballard, L., 1992. Graphic Design Basic: Making a Good Layout. Ohio: North Light Books.

Sihombing, D., 2001. Tipografi dalam Desain Grafis. Jakarta: Gramedia Pustaka Utama.

Soewardikoen, D. W., 2013. Metodologi Penelitian Visual dari Seminar ke Tugas Akhir. Bandung: CV Dinamika Komunika.

M, Winda A., 2013. Asuhan Keperawatan pada An.A dengan Prioritas Masalah Kebutuhan Dasar Nutrisi Kurang dari Kebutuhan Tubuh di Kelurahan Harjosari I Kecamatan Medan Amplas. Tersedia di <repository.usu.ac.id> diakses tanggal 14 Februari 2015.

Bimba-aiueo, 2013. 12 Manfaat Membaca Bagi Anak. Tersedia di <http://www.bimba-aiueo.com/12-manfaat-membaca-bagi-anak/> diakses tanggal 16 Februari 2015. 